\title{
Dinamika Masyarakat Tradisional Kampung Naga di Kabupaten Tasikmalaya
}

\author{
EPON NINGRUM \\ Jurusan Pendidikan Geografi FPIPS, Universitas Pendidikan Indonesia, JI.Setiabudi Bandung. \\ email: epon.ningrum@yahoo.com
}

\begin{abstract}
The dynamics of the Kampung Naga at District Tasikmalaya community is controlled by the custom. Generally, the aim of this research is to analyze the traditional dynamic community of Kampung Naga, especially to: (1) identify the custom of Kampung Naga community; (2) identify the dynamic of the society; and (3) recommend employing society strategy. The research design is using qualitative approach with descriptive method. Researcher as human instrument with the aid of interview guide, observation guide and field note. The subject of this research consists of 5 respondents. The data validity is through triangulation, probing, peer debriefing, and members check. The data analyze through data display, data reduction, verification and conclusion. The result of the research are: (1) the custom consists of testament tradition, mandating, prohibition and consequence; (2) the society dynamic consists of technology changing, occupation, income and life facility ownership; and (3) employing strategy is recommended through adaptive innovation concerning the custom.
\end{abstract}

Key words: dynamics, traditional community, tradition and custom.

\begin{abstract}
Abstrak. Dinamika masyarakat Kampung Naga di Kabupaten Tasikmalaya terkontrol oleh adat istiadat. Secara umum, tujuan penelitian ini adalah untuk menganalisis dinamika masyarakat tradisional Kampung Naga, secara khusus bertujuan untuk: (1) mengidentifikasi adat istiadat masyarakat Kampung Naga; (2) mengidentifikasi dinamika masyarakat; dan (3) merekomendasikan strategi pemberdayaan masyarakat. Disain penelitian menggunakan pendekatan kualitatif dengan metode deskriptif. Peneliti menggunakan alat instrumen utama (human instrument) dengan alat bantu pedoman wawancara, pedoman observasi, dan field note. Subyek penelitian terdiri atas lima orang responden. Keabsahan data melalui triangulasi, probing, peer debriefing, dan members check. Analisis data melalui display data, reduksi data, verifikasi dan kesimpulan. Hasil penelitian adalah: (1) Adat istiadat terdiri atas tradisi wasiat, amanat, pantangan, dan akibat; (2) Dinamika masyarakat terdiri atas perubahan teknologi, mata pencaharian, pendapatan, dan kepemilikan fasilitas hidup; dan (3) strategi pemberdayaan direkomendasikan melalui inovasi yang bersifat adaptif terhadap adat istiadat.
\end{abstract}

Kata kunci: dinamika, masyarakat tradisional, tradisi, dan adat istiadat

\section{Pendahuluan}

Dinamika adalah salah satu identitas kehidupan manusia baik secara individual, kelompok maupun masyarakat. Dinamika masyarakat bersifat universal yakni terjadi pada setiap masyarakat di berbagai tempat, kondisi, dan situasi. Salah satu faktor pendorong terjadinya dinamika masyarakat adalah inovasi (Gillin dan Gillin dalam Saripudin: 2005: 49).

Proses dinamika masyarakat semakin intensif dengan adanya kemajuan ilmu pengetahuan dan teknologi (IPTEK) bidang informasi dan komunikasi. Proses difusi inovasi tidak lagi terkendala ruang dan waktu. Terjadinya adopsi inovasi diharapkan tidak merusak tatanan kehidupan masyarakat yang sudah mapan, melainkan memberikan kebermaknaan bagi peningkatan kehidupan bermasyarakat. S. Susanto (1985: 158), mengemukakan pentingnya kearifan menyikapi inovasi agar memberikan kebermaknaan dan menghindari bahaya degradasi martabat.

Masyarakat dan kebudayaan merupakan dua konsep yang memiliki jalinan fungsional bagi kelangsungan hidup dan dinamika warganya. Menurut Fairchild (1980: 300),

society is a group human being cooperating in the 
pursuit of several of their major interest, invariably including self-maintenance and selfpersuation. Menurut Adiwikarta (1988:17), masyarakat terbagi atas tiga subsistem, yakni: (1) subsistem budaya (cultural system) yang berupa nilai, norma, pengetahuan, dan kepercayaan; (2) subsistem sosial (social system) berupa kelembagaan sosial yang mengatur status dan peran; dan (3) subsistem kepribadian (personality system) yaitu proses dimilikinya kepribadian hingga individu memiliki karakteristik masyarakat.

Kehidupan masyarakat dalam koneksitasnya dengan ruang hidup (living space) dan waktu telah membentuk suatu pola perilaku kehidupan dalam wujud kebudayaan. Menurut Malinowski dalam S. Susanto (1985: 123), culture is an integral composed of partly autonomous, partly coordinated institutions. Selanjutnya dikemukakan bahwa kehidupan bermasyarakat berlandaskan pada cara, kebiasaan, nilai, dan norma yang bersifat kontinyu dan terikat oleh suatu rasa identitas bersama hingga terbentuk adat istiadat.

Kebudayaan yang menguntungkan dan dapat berfungsi mempertahankan eksistensi masyarakat dalam lingkungan alam, biologi dan fisik, akan diteruskan ke generasi berikutnya hingga terbentuk tradisi. Menurut Soekanto (1982: 172177), terdapat tiga fungsi kebudayaan bagi masyarakat, yaitu: (1) karya melindungi masyarakat dari lingkungan alam; (2) karsa untuk mengatur kehidupan bermasyarakat yang disebut adat istiadat; dan (3) cipta untuk mengekspresikan keinginan atau perasaan.

Pada hakikatnya, masyarakat potensial mengalami dinamika. Menurut Sorokin dalam Ningrum (2006:306), terdapat tiga aspek perubahan masyarakat, yaitu: (1) perubahan idea (ideational change); (2) pengaruh unsur budaya material terhadap mental masyarakat (sensational change), dan (3) perubahan ideologi (idealistic change). Sedangkan menurut Bogardus dalam Saripudin (2005: 145), perubahan unsur budaya material lebih cepat karena proses adopsinya tidak selalu memerlukan perubahan mental terlebih dahulu.

Namun demikian, terdapat perbedaan proses dinamika masyarakat terkait dengan lokasi, lingkungan, tingkat inovasi warga, dan fungsi kelembagaan sosial. Pada masyarakat tradisional, dinamika masyarakat terproteksi oleh adat istiadat. Menurut Sajogyo (1985: 91), masyarakat tradisional adalah orang-orang atau suku bangsa yang sudah hidup sesuai dengan tradisi yang tidak terputus-putus. Menurut Mannhein (1987: 44), tradisi adalah tali pengikat yang kuat dalam membangun tata tertib masyarakat, sedangkan adat merupakan wujud ideal dari kebudayaan yang berfungsi sebagai tata kelakuan yang terhimpun dalam adat istiadat.
Menurut Yufuf (1979), pada masyarakat tradisional apabila terjadi pelanggran terhadap adat istiadat, maka perasaan bersalah akan selalu menghantuinya.

Menurut Wesnawa (2010: 9), komitmen masyarakat adat relatif tinggi dalam penerapan konsepsi tata ruang tradisional Bali karena adanya kesadaran budaya masyarakat dan kecintaan terhadap warisan budaya leluhur. Menurut Ningrum (2002: 33), pada masyarakat Kampung Naga mematuhi budaya papagon hirup yakni wasiat amanat, pamali, dan akibat telah menciptakan kehidupan yang harmonis dengan lingkungan sosial dan lingkungan alam, sehingga lingkungan hidup terlestarikan.

Menurut hasil penelitian Dove (1985), masyarakat tradisional di Indonesia memiliki ciri dinamis yang ditandai dengan terjadinya perubahan sosial yang terus menerus sesuai dengan tantangan internal dan kekuatan eksternal. Menurut Kindevatter (1979: 13),

empowering is people gaining an understanding of and control over social, economic, and/or political procces in order to improve their standing in society. Selanjutnya dikemukakan lima prinsip pemberdayaan, (1) need oriented; (2) endigenous; (3) self-reliant; (4) ecologically sound; dan (5) based on structural transformations.

Pemberdayaan dan pengembangan masyarakat memiliki makna yang relatif sama. Menurut Joyomartono (1991: 31), pengembangan masyarakat adalah upaya merealisasikan potensi masyarakat sehingga mampu memenuhi kebutuhan hidup, meningkatkan pengelolaan sumber daya, meningkatkan ilmu pengetahuan dan teknologi, serta penyesuaian tata kemasyarakatan dengan perubahan.

Pemberdayaan merupakan perubahan sosial yang direncanakan sehingga diharapkan terjadinya dinamika masyarakat yang tidak menimbuklan konflik sosial. Inovasi menjadi salah satu faktor pendorong perubahan sosial dan adopsi inovasi menjadi katalisator dinamika masyarakat. Mengacu kepada pendapat Rogers (1983: 157-163), agar inovasi cepat diadopsi oleh masyarakat maka inovasi tersebut hendaknya memiliki karakteristik: adventage relative, compatibility, complexity, triability, dan observanility.

Masyarakat Kampung Naga mengalami dinamika, namun adat istiadat berfungsi sebagai kontrol sosial secara informal (social control informal). Berdasarkan dinamika fenomena lokalitas masyarakat Kampung Naga, maka dirumuskan permasalahan: proses globalisasi semakin intensif seiring dengan kemajuan teknologi informasi dan komunikasi (ICT) yang membawa 
konsekuensi terhadap terjadinya dinamika masyarakat. Di samping itu, masyarakat dan kebudayaannya bersifat dinamis. Kedua hal tersebut akan berdampak pada longgarnya ketaatan terhadap adat istiadat dan hilangnya budaya lokal. Dengan demikian, tujuan penelitian ini adalah (1) mengidentifikasi adat istiadat masyarakat Kampung Naga; (2) mengetahui dinamika masyarakat pada aspek sosial budaya; dan (3) merekomendasikan strategi pemberdayaan masyarakat berbasis adat istiadat.

\section{Metode Penelitian}

Penelitian didesain menggunakan pendekatan kualitatif dengan metode deskriptif. Peneliti menjadi instrumen utama (human instrument) dengan alat bantu pedoman wawancara, catatan lapangan, dan observasi. Validasi internal melalui triangulasi, probing, peer debriefing, dan members check. Subjek penelitian adalah kuncen adat, seorang warga yang mewakili generasi tua, dan seorang pemuda. Variabel penelitian: adat istiadat dan aspek sosial budaya. Analisis data dilakukan melalui empat langkah, yakni: reduksi data, display data, verifikasi dan kesimpulan.

\section{Adat Istiadat Masyarakat Kampung Naga}

Secara geografis, lokasi Kampung Naga berada pada posisi strategis dan ditunjang dengan faktor sarana prasaran transportasi. Lokasi Kampung Naga berada pada jalur transportasi Kota Tasikmalaya dengan Kota Garut, sehingga memudahkan masyarakat melakukan mobilitas. Namun demikian, masyarakatnya masih kuat mempertahankan adat istiadat sehingga termasuk kategori masyarakat tradisional. Dengan demikian dapat diungkapkan suatu asumsi bahwa adat istiadat memiliki daya dukung terhadap kelangsungan hidup masyarakat dan masyarakat memiliki daya adaptabilitas terhadap adat istiadat.

Secara demografis, jumlah keluarga dipertahankan tidak lebih dari 99 KK dan jumlah bantunan tetap 102 buah. Mereka menempati wilayah seluas 1,5 ha (legana sa naga). Masyarakat Kampung Naga dipersatukan oleh adat istiadat yang terus dipertahankan oleh seluruh warganya, sehingga dapat dikategorikan sebagai masyarakat tradisional. Pada masyarakat tradisional, tradisi masih kuat dipelihara dan dipertahankan sehingga warganya memiliki sifat-sifat tradisional (Sajogjo, 1985: 68). Warga masyarakat kampung naga

Tabel 1

Adat Istiadat Masyarakat Tradisional Kampung Naga

\begin{tabular}{|c|c|c|c|}
\hline No. & Tradisi & Aspek & Keterangan \\
\hline \multirow[t]{4}{*}{1.} & \multirow[t]{4}{*}{ Wasiat } & Rumah & $\begin{array}{l}\text { Material, jenis bangunan, arah dan } \\
\text { ukuran, ruangan. }\end{array}$ \\
\hline & & Bertani & Bibit padi, pemeliharaan, panen \\
\hline & & Benda pusaka & Peninggalan leluhur \\
\hline & & Tempat & $\begin{array}{l}\text { Hutan Naga (larangan) dan kawasan } \\
\text { makam (kawasan pasarean) }\end{array}$ \\
\hline \multirow[t]{2}{*}{2.} & \multirow[t]{2}{*}{ Amanat } & Pola hidup & Sederhana, kebersamaan, dan damai \\
\hline & & upacara & $\begin{array}{l}\text { Kelahiran, tingkeban, khitanan, } \\
\text { perkawinan, kematian, nyepi, mendirikan } \\
\text { tumah/bangunan, bertani, dan hajat sasih. }\end{array}$ \\
\hline 3. & Akibat & $\begin{array}{l}\text { Pelanggran terhadap } \\
\text { tradisi }\end{array}$ & Perasaan bersalah \\
\hline \multirow[t]{3}{*}{4.} & \multirow[t]{3}{*}{ Larangan } & Ucapan & 12 macam upacara \\
\hline & & Perbuatan & $\begin{array}{l}\text { Kerjabakti, kegiatan bersama, ngobrol, } \\
\text { dan rapat }\end{array}$ \\
\hline & & Benda & $\begin{array}{l}\text { Material dari tembok, kursi tamu, padi } \\
\text { varietas baru, dan listrik. }\end{array}$ \\
\hline
\end{tabular}


memiliki pola pikir dan perilaku sebagai hasil penyesuaian (conformity) dan ketaatan terhadap tradisi yang diwariskan dari generasi ke generasi melalui perintah dan larangan. Masyarakat menjadi wahana proses pewarisan nilai sosial budaya, inovasi, dan transformasi sosial. Tradisi terbentuk melalui proses pewarisan nilai sosial budaya (enculturation) hingga terbentuk adat istiadat. Ketaatan dan pewarisan budaya yang berupa tata nilai, norma dan kaidah sosial terus berlangsung. Kuncen menjadi tokoh tunggal (key person) dalam melestarikan dan pewarisan budaya lokal. Adat istiadat menjadi penuntun pola prilaku baik dan tidak baik, keharusan dan pantangan.

Homogenitas masyarakat, tidak hanya berdasarkan pada adat istiadat melainkan dipersatukan oleh kesamaan leluhur dan ikatan tempat tinggal sebagai ruang hidup bersama (living space). Adat istiadat bagi masyarakat kampung naga memiliki daya pemersatu (sentripetal), sehingga dapat melemahkan kekuatan eksternal yang dipandang memiliki daya pemecah (sentrifugal) bagi kehidupan bermasyarakat. Adat istiadat menjadi falsafah hidup yang terangkum pada empat tradisi yaitu: wasiat, amanat, larangan, dan akibat.

Wasiat merupakan tradisi warisan leluhur yang harus ditaati dan dilestarikan oleh seluruh warga (seuweu siwi naga). Wasiat tentang rumah berkenaan dengan material, jenis bangunan, arah dan ukuran bangunan, serta jumlah ruangan. Material bahan bangunan terdiri atas: batu (tatapakan), kayu/bambu (tiang, dinding, dan lantai), ijuk dan daun tepus (atap). Jenis bangunan adalah rumah panggung tradisional berukuran $8 \times 5$ meter yamg memanjang arah Barat-Timur. Rumah terdiri atas lima ruangan yaitu: ruang depan, ruang tengah, ruang tidur, ruang goah, dan dapur.

Wasiat bertani dilakukan secara tertib mengikuti adat leluhur. Bagi masyarakat kampung naga, padi memiliki makna ekonomi dan nilai keyakinan, sehingga diperlakukan secara khusus. Kegiatan bertani diawali dan diakhiri dengan upacara. Tradisi bertani berkenaan dengan bibit padi, pemeliharaan, dan panen. Bibit padi menggunakan padi buhun, tidak menggunakan pupuk kimia dan pestisida, dan hasil panen disimpan di lumbung padi. Wasiat tersebut hanya berlaku di kawasan kampung naga.

Masyarakat kampung naga memiliki beragam benda pusaka peninggalan leluhur yang keberadaanya dikeramatkan. Benda pusakan disimpan di Bumi Ageung yang dijaga oleh perempuan tua tidak bersuami dan memiliki garis keturunan dengan leluhur. Sedangkan wasiat hutan naga tidak boleh dijamah oleh siapa pun. Hutan naga merupakan kawasan suci yang tidak boleh tersentuh manusia.

Amanat yaitu pesan leluhur untuk mempertahakan tradisi pola hidup sederhana dan damai, serta melaksanakan upacara ritual. Ungkapan teu saba, teu boga, teu banda teu boga, teu weduk teu bedas, teu gagah teu pinter, dan amanat ti kolot sacekap-cekapna sakieu wae (tidak bepergian, tidak punya, tidak memiliki harta kekayaan, tidak kebal tidak kuat, tidak gagah tidak pandai, dan sekian amanat dari leluhur). Ungkapan tersebut memiliki filosofi hidup yang sifatnya dogmatis.

Terdapat 12 macam upacara yang diamanatkan untuk dilaksanakan oleh warga masyarakat kampung naga. Ketatanan melaksanakan wasiat tersebut menunjukkan keteraturan hidup bermasyarakat. Amanat tersebut, merefleksikan kehidupan yang bersahaja, mengutamakan kedamaian, dan kebersamaan.

Larangan adalah tradisi tentang tabu ucapan, tabu perbuatan, dan tabu benda. Larangan mengucapkan kata-kata tertentu, melakukan perbuatan pada waktu tertentu, dan menggunakan benda/material bangunan bagi seluruh warga masyarakat. Larangan tersebut berlaku secara lokalit di kawasan kampung naga.

Tabu ucapan diantaranya menggunakan kata kering (garing), berbicara pada hari/bulan pantangan (selasa, rabu, dan sabtu/ shafar), dan pada saat berlangsungnya upacara. Tabu perilaku yaitu melakukan kerja bakti, kegiatan bersama, ngobrol/diskusi, dan musyawarah/rapat pada hari/ bulan pantangan dan pada saat upacara berlangsung. Tabu menggunakan benda /material bangunan yang terbuat dari tembok.

Akibat adalah tradisi merasa bersalah terhadap leluhur karena ketidaktaatan terhadap perintah atau larangan adat leluhur. Budaya akibat merupakan konsekuensi moral atas setiap pelanggaran terhadap adat istiadat dengan perasaan bersalah terhadap leluhur sebagai hukumannya. Tradisi ini tidak memiliki sanksi nyata, tetapi telah menjadi bagian dari kepribadian masyarakat. Hal ini merupakan keberhasilan sosialisasi dan enkulturasi sehingga generasi muda secara kultural terproteksi (Soekanto, 1982: 123; Mannhein, 1987: 79).

Bagi masyarakat kampung naga, budaya akibat memiliki nilai spiritual tinggi, meski sanksinya hanya berupa dosa atau perasaan bersalah tetapi dirasakan oleh pelakunya sebagai beban yang menyiksa batin, lepas dari diketahui tidaknya pelanggaran tersebut oleh orang lain. Budaya akibat menunjukkan pengetahuan dan kesadaran yang tinggi yang sama dengan sanksi agama (Yusuf: 1979: 163). Larangan, akibat, dan kuncen merupakan informal kontrol sosial (social control informal) yakni kontrol yang bersifat psikologis dan nonfisik, berupa tekanan mental 
terhadap warganya yang tidak mematuhi perintah dan pantangan.

\section{Dinamika Masyarakat Kampung Naga}

Pada masyarakat Kampung Naga, adat istiadat memiliki makna mendalam yang diperoleh secara turun temurun yang terhimpun ke dalam adat leluhur. Masyarakat menjadi wahana proses pewarisan nilai sosial budaya, inovasi, dan transformasi sosial. Tradisi terbentuk melalui proses pewarisan nilai sosial budaya (enculturation) hingga terbentuk adat istiadat. Adat istiadat berfungsi sebagai kontrol sosial bagi dinamika masyarakat.

Inovasi merupakan salah satu faktor pendorong dinamika masyarakat, sedangkan tingkat inovasi masyarakat menjadi indikator dan katalisator bagi terjadinya transformasi sosial. Proses difusi inovasi tidak lagi terbatas ruang dan waktu, melainkan terseleksi oleh adat istiadat, sifat dan tingkat inovasi masyarakat dalam menyikapi suatu unsur baru. Sikap masyarakat Kampung Naha terhadap suatu inovasi dipengaruhi oleh adat istiadat.

Bagi masayarakat kampung naga, adat istiadat bersifat proteksionistik terhadap perubahan yang dipandang dapat mengganggu keseimbangan sosial. Namun demikian, masyarakat tradisional di Indonesia memiliki ciri dinamis yang ditandai dengan terjadinya perubahan sosial yang terus menerus sesuai dengan tantangan internal dan kekuatan eksternal (Dove, 1985: 287). Faktor eksternal yang tidak bertentangan dengan adat istiadat menjadi salah satu sumber dinamika kehidupan bagi masyarakat Kampung Naga.

Kehidupan masyarakat Kampung Naga mengalami dinamika pada aspek sosial, ekonomi, dan budaya yang meliputi perubahan teknologi, mata pencaharian, pendapatan dan kepemilikan fasilitas hidup. Fenomena sosial tersebut menurut Sorokin (Ningrum; 2006: 463) adalah merupakan konsekuensi dari hakikat masyarakat yang potensial mengalami perubahan, yakni perubahan idea (ideational change), pengaruh unsur budaya material terhadap mental masyarakat (sensational change), dan perubahan ideologi (idealistic change). Bagi masyarakat, aspek teknologi merupakan unsur budaya yang lebih cepat berubah karena proses adopsinya tidak selalu memerlukan perubahan mental terlebih dahulu.

Masyarakat Kampung Naga memiliki keterampilan membuat peralatan rumah tangga dari bambu. Kebiasaan tersebut telah mengalami perubahan yakni dari orientasi kebiasaan ke arah orientasi bisnis. Hal ini berkenaan dengan perubahan pengetahuan dan keterampilan usaha kerajian, yakni dari teknologi tradisional ke teknologi tepat guna. Perubahan tersebut menghasilkan produk kerajinan yang memiliki nilai ekonomi tinggi, dengan jangkaun pemasaran ke perkotaan, hotel, dan luar negeri.

Perubahan tersebut merupakan dinamika masyarakat yang bersumber dari kebutuhan untuk meningkatkan efisiensi dan peningkatan produktivitas. Bagi masyarakat Kampung Naga, usaha kerajinan tidak terproteksi adat istiadat, sehingga perubahannya tidak menimbulkan kegoncangan sosial (Margono dalam Ningrum; 2006: 478). Usaha kerajinan sebagai kebiasaan untuk mengisi waktu luang, memanfaatkan sumber alam yang ada, dan untuk memenuhi kebutuhan telah mengalami peningkatan efisiensi dan produktivitasnya.

Sesungguhnya, mata pencaharian utama adalah bertani yang terproteksi secara adat istiadat, sehingga usaha kerajinan menjadi mata pencaharian sampingan. Artinya, masyarakat Kampung Naga memiliki mata pencaharian baru dalam bidang usaha kerajinan. Fenomena tersebut merupakan salah satu ciri perubahan sosial yaitu perubahan yang terjadi pada aspek material maupun immaterial. Perubahan bentuk dan model produksi kerajinan (aspek material), sedangkan pengelolaan usaha kerajinan (aspek immaterial).

Seiring dengan meningkatnya produktivitas usaha kerajinan, maka pendapatan masyarakat mengalami peningkatan pula yang berdampak pada kepemilikan fasilitas hidup. Dinamika masyarakat Kampung Naga memiliki dampak terhadap peningkatan kesejahteraan. Fasilitas hidup yang dimiliki oleh masyarakat adalah alat transfortasi, media informasi dan hiburan, mebeler, kepemilikan lahan, dan rumah permanen. Rumah panggung tradisional memiliki perlengkapan yang relatif sama dengan masyarakat umumnya. Alat transfortasi, kepemilikan lahan, dan rumah permanen berada di luar kampung naga, yakni di kecamatan Cigalontang Kabupaten Tasikmalaya.

Fenomena tersebut menunjukkan terpeliharanya solidaritas, pola hidup sederhana, dan damai di kampung naga. Dinamika masyarakat tradisional kampung naga merupakan upaya penyesuaian (conformity) antara kebutuhan, potensi alam, dengan adat istiadat dengan, sehingga sifat-sifat masyarakat tradisional tetap terpelihara.

\section{Strategi Pemberdayaan Masyarakat}

Pemberdayaan masyarakat adalah suatu proses aktualisasi potensi yang terdapat di lingkungan masyarakat, baik potensi sosial dan budaya maupun fisis geografis agar memiliki 
EPON NINGRUM. Dinamika Masyarakat Tradisional Kampung Naga di Kabupaten Tasikmalaya

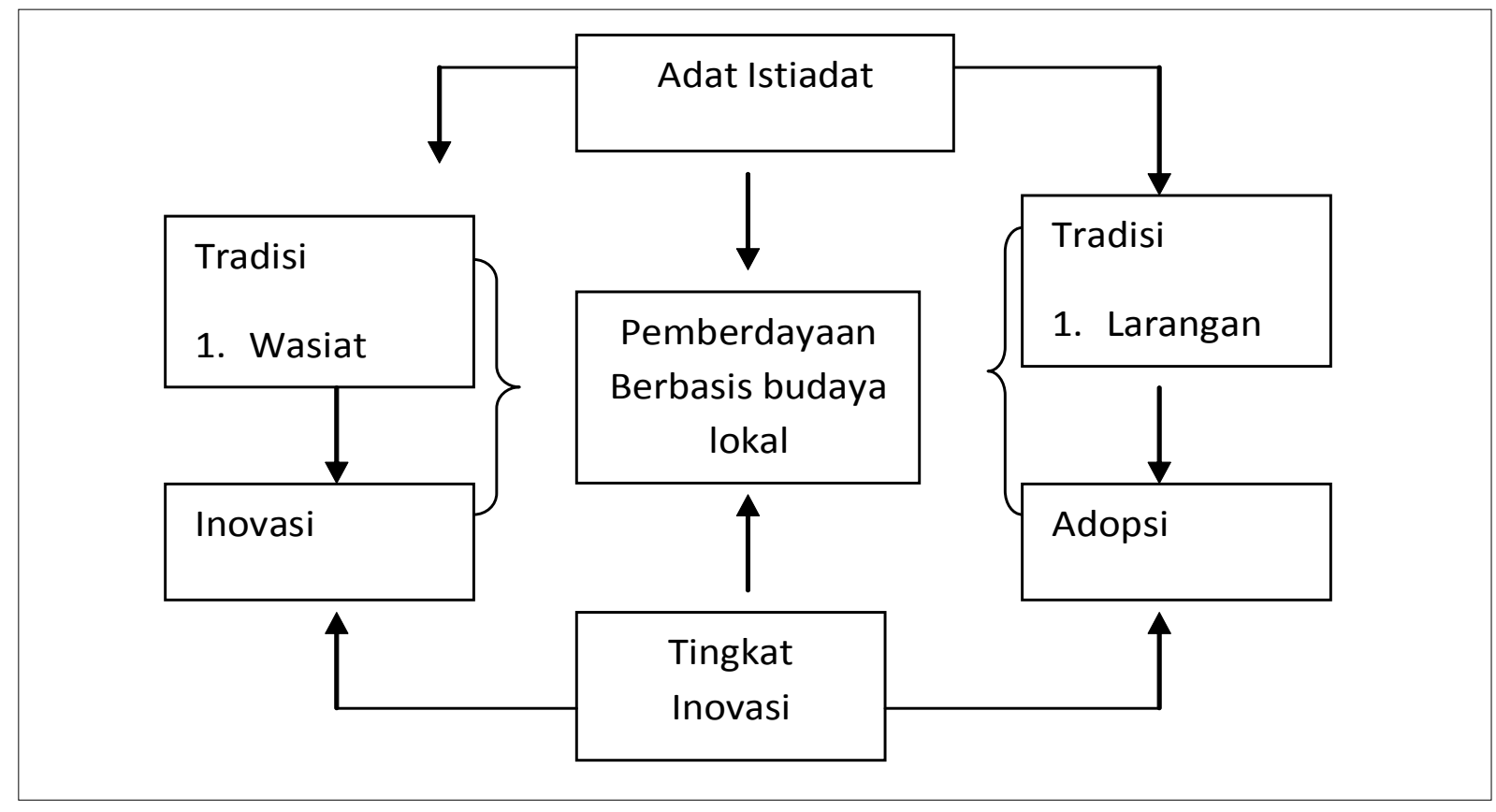

Gambar 1

Pemberdayaan Berbasis Budaya Lokal

eksistensi dan kemandirian. Menurut Kindevatter (1979: 79),

empowering is people gaining an understanding of and control over social, economic, and/or political proces in order to improve their standing in society.

Konsep pemberdayaan dan pengembangan memiliki makna yang sama sebagai upaya peningkatan kesejahteraan melalui pendayagunaan potensi masyarakat. Eksistensi dan kemandirian masyarakat bersumber dari kekuatan internal dan tidak bersifat destruktif terhadap tatanan kehidupan yang sudah mapan.

Pengembangan masyarakat adalah upaya merealisasikan potensi masyarakat sehingga mampu memenuhi kebutuhan hidup, meningkatkan pengelolaan sumber daya, meningkatkan ilmu pengetahuan dan teknologi, serta penyesuaian tata kemasyarakatan dengan perubahan (Joyomartono; 1991: 94).

Pemberdayaan masyarakat kampung naga adalah upaya pendayagunaan potensi internal yang disesuaikan dengan adat istiadat. Pada pelaksanaannya mengacu pada strategi dan prinsip-prinsip berikut: (1) need oriented; (2) endigenous; (3) self-reliant; (4) ecologically sound; dan (5) based on structural transformations (Kindevatter: 1979: 155). Strategi pemberdayaan masyarakat kampung naga divisualisasikan pada gambar 1.

Kebutuhan menjadi landasan bagi pemberdayaan karena dapat melahirkan kesadaran, keinginan, dan upaya bagi terpenuhinya. Identifikasi kebutuhan secara partisipatif dapat menentukan kebutuhan nyata (felt needs). Adat istiadat merupakan potensi lokalit yang dapat didayagunakan bagi inovasi immaterial yang tidak terproteksi. Hal ini dapat memelihara rasa tanggung jawab (sense of responsibility) terdapat tradisi yang sudah mapan. Keberhasilan upaya memenuhi kebutuhan maka cara tersebut akan dilaksanakan secara berkelanjutan. Lingkungan sosial budaya dan lingkungan alam merupakan potensi internal yang dapat didayagunakan. Keberhasilan pemberdayaan dapat menimbulkan perubahan secara struktural ke arah yang lebih baik, namun tidak bertentangan dengan adat istiadat dan tanpa merusak budaya lokal.

Masyarakat Kampung Naga bersifat terbuka terhadap inovasi yang tidak bertentangan dengan adat istiadat. Keinovatifan tersebut menjadi kekuatan motivasional bagi inovasi yang memiliki daya suai (adaptability) terdapat budaya lokal dan daya tahan (homeostatic) bagi tatanan kehidupan bermasyarakat. Mereka telah mengalami perubahan sosial ekonomi, tetapi tidak terjadi konflik sosial. Hal ini karena inovasi yang diadopsi tidak bertentangan dengan adat istiadat.

Inovasi merupakan salah satu unsur pemberdayaan, sedangkan keinovatifan menjadi prasyarat berlangsungnya proses pemberdayaan. Menurut S. Susanto (1985: 159), keinovatifan 
masyarakat yang mendukung terhadap pemberdayaan dipengaruhi oleh pendidikan yang tidak didasarkan pada sosialisasi tradisional (traditional socialization). Bagi masyarakat kampung naga, pendidikan (sekolah) tidak bertentangan dengan adat istiadat. Hal ini ditununjukkan dengan beberapa orang yang sudah mendapat gelar sarjana.

Upaya pemberdayaan masyarakat kampung naga dapat dilakukan melalui strategi inovasi yang memiliki daya suai (adaptability innovation) dengan budaya lokal. Mengacu kepada pendapat Rogers (1983: 157-163), agar inovasi cepat diadopsi oleh masyarakat maka inovasi tersebut hendaknya memiliki karakteristik: adventage relative, compatibility, complexity, triability, dan observanility. Masyarakat kampung naga relatif mudah mengadopsi inovasi apabila secara ekonomi menguntungkan, secara teknis mudah dilaksanakan, secara budaya tidak bertentangan dengan adat istiadat, secara praktis dapat dicoba, dan bersifat kasat mata.

Difusi inovasi dapat dilakukan secara partisipatif yakni dengan melibat masyarakat untuk menghindari kecurigaan dan rasa tidak percaya warga terhadap pihak luar. Warga masyarakat yang dapat dilibatkan adalah tokoh generasi muda dan kuncen karena mereka dipandang sebagai tokoh kunci (key opinion) dan tokoh pimpinan (leaders opinion) bagi masyarakat kampung naga. Selain itu, pihak luar yang sudah dikenal oleh masyarakat (homofili) dapat dijadikan sebagai agen perubahan (change agents).

Unsur inovasi adalah yang dapat memenuhi kebutuhan masyarakat, tidak bertentangan dengan adat istiadat, berupa material dan bersifat kasat mata menjadi pilihan agat relatif mudah diadopsi oleh masyarakat (Kindevatter, 1979: 79; Rogers: 1983: 157-163). Hal ini merupakan peluang yang dapat didayagunakan bagi percepatan proses pemberdayaan masyarakat. Proses pemberdayaan akan berkelanjutan manakala masyarakat merasakan manfaat ekonomis dan tidak bertentangan dengan tatanan kehidupan yang sudah mapan yakni adat istiadat, sehingga budaya lokal terlestarikan.

\section{Simpulan dan Saran}

Mematuhi dan mewariskan adat istiadat pada masyarakat Kampung Naga adalah suatu keharusan yang sifatnya dogmatis. Adat istiadat telah membentuk kepribadian warga sehingga masyarakat memiliki sifat-sifat tradisional. Sifatsifat lokalitas dilestarikan dalam pola pikir, pola tata kelakuan, dan pola kebudayaan. Budaya wasiat, amanat, larangan, dan akibat merupakan tradisi leluhur yang terangkum ke dalam adat istiadat. Aspek kehidupan masyarakat Kampung Naga yang tidak terproteksi oleh adat istiadat telah mengalami dinamika, yakni terjadinya perubahan ekonomi masyarakat ke arah yang lebih baik. Peningkatan kesejahteraan masyarakat secara berkelanjutan menuju kekemandirian dapat diupayakan dengan strategi pemberdayaan masyarakat melalui inovasi yang memiliki adaptabilitas dengan budaya lokal.

\section{Daftar Pustaka}

Adiwikarta, S. (1988). Sosiologi Pendidikan: Isue dan Hipotesis tentang Hubungan Pendidikan dengan Masyarakat. Jakarta: Departemen P \&K.

Dove, R. Michael (ed). (1985). Peranan Kebudayaan Tradisional Indonesia dalam Modernisasi. Jakarta: Yayasan Obor Indonesia.

Fairchild. (1980). Dictionary of Sosciology. New Jersey: Little field Adam \& Co.

Joyomartono, M. (1991). Perubahan Kebudayaan dan Masyarakat dalam Pembangunan. Semarang: IKIP Semarang.

Kindevater, S. (1977). Non Formal Education As An Empowering Process. Amhers: Center For International Education.

Mannhein. (1987). Sosiologi Sistematis. Jakarta: Bina Aksara.

Ningrum, E. (2006). Tempat Ruang dan Sistem Sosial. Bandung: UPI Press.

Rogers, M.Everett. (1983). Diffusion of Innovation. 3ed. New York. The Free Press.

Sajogjo, P. (1985). Sosiologi Pembangunan. Jakarta: FPS IKIP Jakarta-BKKBN.

Saripudin, D. (2005). Mobilitas dan Perubahan Sosial. Bandung: Masagi Foundation.

Soekanto, S. (1982). Sosiologi suatu Pengantar. Jakarta: Rawali Pers.

Susanto, S. Astrid. (1985). Pengantar Sosiologi dan Perubahan Sosial. Bandung: Bina Cipta.

Yusuf, M. (1979). Peranan Ulama Memasyarakatkan Sadar Lingkungan. Mimbar Ulama edisi Nopember.

Jurnal:

Ningrum, E. (2002). Budaya Papagon Hirup dan 
EPON NINGRUM. Dinamika Masyarakat Tradisional Kampung Naga di Kabupaten Tasikmalaya

Pamali Manifestasi Kepedulian Masyarakat terhadap Kelestarian Lingkungan Hidup. Gea. vol.2, no.3, April, pp. 27-33.
Wesnawa,IGA. (2010) Dinamika Pemanfaatan Ruang Berbasis Kearifan Lokal di Kabupaten Buleleng Provinsi Bali. Forum Geografi. vol.24, no.1, Juli, pp. 1-11. 